\title{
Is there a role for traditional governance systems in South Africa's new water management regime?
}

\author{
Farai Kapfudzaruwa and Merle Sowman* \\ Department of Environmental and Geographical Science, University of Cape Town, Private Bag X3, Rondebosch 7701, South Africa
}

\begin{abstract}
The transition to democracy in South Africa in 1994 catalysed new forms of governance in all sectors of society including water resource management. This paper examines the extent to which traditional governance systems have been acknowledged and incorporated into these new water management institutions and approaches. The research focused on understanding the cultural, religious and customary practices and rules relevant to water resource management as well as the roles of traditional leaders in 2 water user associations in the Eastern Cape Province. Findings from the research reveal that both state governance systems and traditional governance systems are relevant to water resource management in the study areas. However, management is predominantly guided by state-driven strategies which are based on statutory legal systems. Yet, traditional governance systems, including customary laws and cultural and religious practices, have an important role to play in achieving the purposes of the water user associations. Failure to acknowledge and incorporate aspects of these traditional governance systems may undermine the ability of government to achieve the objectives of the National Water Act.
\end{abstract}

Keywords: traditional governance systems, cultural, religious, customary practices, water user associations

\section{Introduction}

The transition from Apartheid to democracy in South Africa in 1994 resulted in a massive law-reform process in all sectors of society including water resource management. Water policy and legislation during the Apartheid era were designed to benefit the needs of the dominant communities in society at the expense of the majority of the indigenous population (Tewari, 2001). Under the Water Act of 1956, water was controlled through a riparian system where access to water was tied to the ownership of land. The new legal framework in South Africa focuses on redressing the inequalities of the past by involving users in water resource management and reforming procedures for allocating water (Schreiner et al., 2004). It provides an enabling framework for contributing to poverty alleviation and can be regarded as a tool to enhance social and environmental justice (Schreiner et al., 2004; Van Koppen et al., 2002).

The post-Apartheid approach to water resource management (WRM) has been guided by global trends that include a shift from supply to demand management, decentralisation of water management decisions and a more integrated and participatory approach to WRM (Franks et al., 2004; Cleaver et al., 2005; Sokile et al., 2003). Fundamental to this new approach is the active involvement of an informed public in the management and allocation of South Africa's scarce water resources. Both the Water Services Act (WSA), No. 108 of 1997 (RSA, 1997), and the National Water Act (NWA), No. 36 of 1998, (RSA, 1998) are based on principles of participation and social justice and contain provisions that require the involvement of citizens in the management of water resources. To achieve this, the post-Apartheid legal framework on water resource

\footnotetext{
* To whom all correspondence should be addressed.

III +2721 6502866; fax: +27216503791 ;

e-mail: Merle.Sowman@uct.ac.za

Received 15 September 2008; accepted in revised form 14 August 2009.
}

management provides for the establishment of new water management institutions such as catchment management agencies (CMAs) and water user associations (WUAs). These new institutions are required to ensure representation of all water user interest groups in their structures and the management of water resources at a more localised level.

Whilst South Africa's new approach to WRM is considered progressive in terms of international trends and practices (Sokile et al., 2003; Muller, 2000), incorporation of traditional systems of governance including the customary practices and laws relevant to WRM, have been largely overlooked. In a critique of the evolution of water management institutions in Tanzania, Sokile et al. (2003) highlight the problems of ignoring traditional and informal institutions - especially traditional by-laws, norms and restrictions. Their research found that village-based informal institutions are often not formally involved in new water management institutions such as WUAs and they question whether these newly-created local level management institutions are meeting the expectations of the poorest of the poor. They go on to criticise the failure of efforts to learn from local informal institutions and report that local communities generally prefer traditional conflict resolution approaches (Sokile et al., 2003). They call for a sound mix of formal-informal institutional arrangements and recommend that the elements of existing local institutions, in particular informal traditional arrangements, should be incorporated into new management systems (Sokile et al., 2003).

From an African perspective, water is not only of social and economic importance, but also of cultural and spiritual significance (Zenani and Mistri, 2005). Indigenous knowledge systems (IKS) used to manage natural resources, mostly transferred through oral tradition from generation to generation, are 'intimately connected to the broader framework of people's cosmology and world view, which is embedded within their physical, spiritual and social landscape' (Hirsch and O'Hanlon, 1995 p. 268). Despite the disenchantment of the 
physical, spiritual and social landscape of indigenous African people by colonisation, there is still a strong body of religious functionaries, traditional healers (izangomas) and traditional leaders who embrace these cultural and spiritual values. These individuals' services play a crucial role in their communities and in the management of natural resources. Even though the NWA promotes and accommodates the efficient social use of water resources, there seems to be very little understanding on the use of water for cultural and religious activities, the values attached to these uses, and the manner in which these affect management decisions (Zenani and Mistri, 2005). In many rural settings in Africa, water is considered a common pool resource whose access, use and management is usually informed by customary rules that form part of a complex system of traditional governance. These rules may be guided by cultural and religious beliefs and practices and are integral to traditional governance systems.

Historically, in South Africa, traditional leaders were mainly responsible for the management of water resources in their rural communities. However, during the Apartheid era, the roles and powers of traditional leaders were curtailed, and most aspects of decision making concerning water resources were vested in the Apartheid government. The 'homelands' policy was an instrument of the Apartheid government whereby 'black' Africans were forced to move and become citizens of designated rural 'homeland' areas. The Bantu Authorities Act (1951) and the Bantu Self-Government Act (1959) provided for the establishment and development of 'homelands' in South Africa between 1950 and 1954. In the homelands, where most Africans resided, the homeland government was responsible for managing water resources whilst delegating other responsibilities such as operation and maintenance of water supply systems to government-controlled water boards (Van Koppen et al., 2002). Although South Africa's new democratic government has recognised the institution of traditional leaders by establishing the national and provincial Houses of Traditional Leaders (HOTL), this paper argues that the state has not provided adequate mechanisms for the consideration of traditional governance systems in the new dispensation for water management in South Africa. The extent to which these cultural practices and customary rules related to traditional water governance systems have been acknowledged and incorporated into new water management institutions and approaches in South Africa, is the subject of this paper. A key focus is on the role of traditional governance systems in WRM in a former homeland area of South Africa where new water management institutions are being introduced.

The paper draws largely on research conducted in the Mzimvubu to Keiskamma Water Management Area (WMA) 12 in the Eastern Cape Province in South Africa during 2007 (Fig. 1). The eDikeni WUA near Alice and Masikhanye WUA which is located $100 \mathrm{~km}$ north-west of King Williams Town, were selected as case study areas within the WMA 12 (Fig. 1). These areas, both former homelands, are in a rural setting, where traditional leaders and cultural practices have played a significant role in the governance and functioning of the community - especially in natural resource allocation and use since the pre-colonial era (Turner and Meer, 2001; Meer and Campbell, 2007). The Masikhanye WUA and the eDikeni WUA comprise 8 and 19 villages, respectively. At present the eDikeni WUA has been established whilst the Masikhanye WUA is in the process of being established. Both these WUAs tend to be single-sector WUAs focusing on water issues related to agriculture.

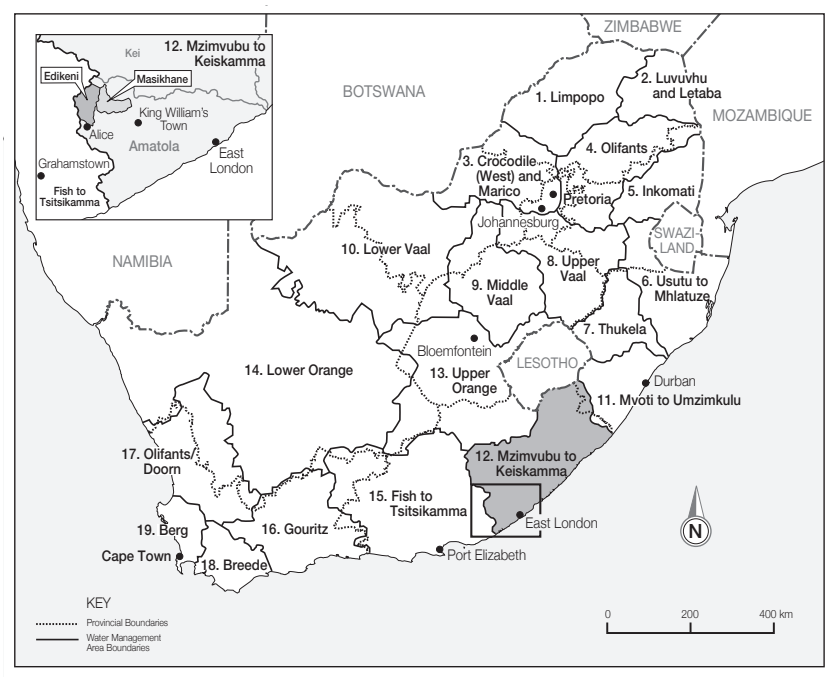

Figure 1

Locality Map

\section{Research methodology}

The paper utilised methodological and investigator triangulation (Denzin, 1970; Jick, 1979; Kimchi et al., 1991) and employed various methods including workshops, transect walks, interviews, review of relevant documents and archival materials as well as field observations. The use of multiple data sources to examine the same dimension of a research problem enhanced the validation process by ensuring that weaknesses inherent in 1 approach were counterbalanced via strengths in another (Denzin, 1970; Jick, 1979). Multiple observers in the research process also enhanced the reliability of the data by comparing data from different individuals for consistency.

At the outset of the research, participatory workshops were held with members of the 2 WUAs, namely Masikhanye and eDikeni, in order to gain information and insights on cultural and religious practices associated with water use as well as the role of traditional governance systems in WRM in the area. A secondary purpose of the workshops was to identify and discuss issues and challenges regarding the process of establishing the WUAs.

In both study areas, transect walks were undertaken with members of the WUAs, in order to identify areas and sites, in or adjacent to water courses, that were considered important in terms of religious and cultural practices. These transect walks were also important in validating the data from the workshops. Following these walks, important sites where cultural practices and religious ceremonies were practised, were demarcated on a map. This information was then discussed and verified with a broader group of WUA participants, including interim WUA committee members, at workshops held in both WUAs.

Semi-structured interviews were also conducted with key stakeholders involved in water provision and management in the study area. The interviews focused largely on investigating the role played by traditional leaders and other functionaries, customary rules and cultural practices in historic and existing water management institutions in the case study areas. The $1^{\text {st }}$ author also participated in a meeting of the Eastern Cape HOTL and was given an opportunity to ask questions regarding their understanding of, and role in, new water management governance arrangements in South Africa. 


\section{The new governance framework for IWRM in South Africa}

The advent of democracy in South Africa in 1994 resulted in the formulation of a new Constitution and a massive law-reform process, including radical changes to the legislation governing water management. The Constitution (Act 108 of 1996) laid the foundation upon which all policies and legislation, including the NWA and WSA were formed. The preamble of the Constitution emphasises the imperative to redress imbalances of the past regarding water resource allocation and management whilst still respecting all citizens' constitutional rights (Glazewski, 2005).

The NWA provides for the reform of water law and places the government as the public trustee of South Africa's water resources to ensure '... that water is protected, used, developed, conserved, managed and controlled in a sustainable and equitable manner for the benefit of all persons and in accordance with its constitutional mandate' (NWA, 1998 s3(1)). The NWA encourages decision makers to be proactive so as to promote the participation of relevant stakeholders. Stakeholder involvement is ensured in the Act by devolving power from national to local level through the establishment of new water management institutions (WMI) such as CMAs which are meant to manage water resources within WMAs. The CMAs will devolve certain responsibilities of management of water resources at the local level to WUAs (NWA, 1998 Chapters 7 \& 8).

According to the NWA, CMAs are supposed to manage water resources within the WMAs. Since these WMAs are based on hydrological boundaries, they can cut across the administrative boundaries of provinces and districts. The purpose of establishing the CMAs is to 'delegate water management to the regional or catchment level and to involve local communities within the framework of the national water resource strategy' (RSA, 1998). Each CMA is responsible for the creation of a catchment management strategy (CMS) for their area of jurisdiction, and, ultimately, also to carry out functions such as water resource planning in the catchment, registration, water charge collection, water use authorisation, and licensing.

The CMA will devolve water management activities to WUAs. The WUAs include a group of water users who wish to work together because of a common interest. The purpose of a WUA is to enable water users to cooperate and pool their resources (financial, human resources and expertise) to effectively carry out water-related activities (RSA, 1998). The functions of the WUAs depend on their constitution and include the following main functions: to conserve water resources; to prevent unlawful use of water; to supervise the use of the water resources in their area of jurisdiction; to investigate water quality and water use; and to construct, operate and maintain waterworks for draining land and supplying water. The National Water Resource Strategy (NWRS) of 2004 outlines the key strategies, objectives, plans, guidelines and procedures for implementing the provisions under the NWA (RSA, 2004a)

The law reform process in South Africa also led to the promulgation of the Water Services Act (No. 108 of 1997) which provides the rights of access to basic water and sanitation as well as the right to institutional structures responsible for providing water. The main goals of this Act are to establish the norms and standards for tariffs with regards to water provision, provide financial assistance to water service institutions and promote effective water resource management and conservation (Glazewski, 2005). In addition to the CMAs and the WUAs, the NWA provides for different water management institutions at different levels (Fig. 2). The rationale behind setting up these institutional structures is to create a more equitable and participatory system of water use and management.

The Minister of Water and Environmental Affairs (formerly the Minister of Water Affairs and Forestry) has the overall responsibility for effective water management in South Africa. The Department of Water Affairs (DWA) (formerly the Department of Water Affairs and Forestry (DWAF)) is responsible for carrying out all aspects of the NWA delegated to it by the Minister. DWAF's overall focus is on managing the national water management policy and ensuring that all water management institutions are performing their roles and responsibilities effectively. As outlined in Fig. 2, a wide array of institutions is involved in implementing the IWRM approach. This new institutional framework places great emphasis on the establishment of new institutions and laws, and does not make reference to the incorporation of customary laws or existing formal and informal institutions that play a role in water management.

\section{Role of traditional authorities in water resource management (WRM) - past and present}

Prior to colonisation and Apartheid in South Africa, traditional systems of governance characterised most forms of administration and governance in rural communities (RSA, 2003; Turner and Meer, 2003). Traditional leaders were responsible for managing natural resources such as water and administering other functions such as mediating conflicts and allocating land. These functions were mainly informed by cultural practices and customary rules.

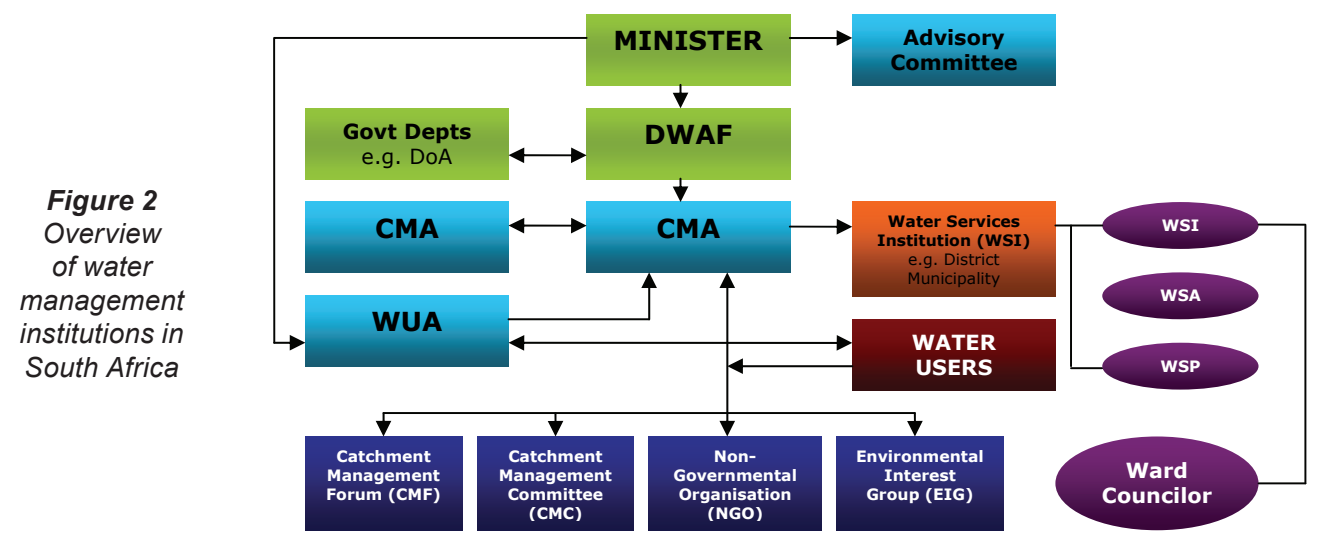

Adapted from: James 2003 
During Apartheid, the homeland government held decisionmaking powers for most aspects of water management but delegated certain responsibilities to traditional chiefs (Van Koppen et al., 2002). Within the rural communities, chiefs/chieftainesses and their headmen were the main contact persons for the homeland government and any other outsiders intervening in issues concerning water supply facilities. Specific tasks, such as the operation and maintenance of water supply systems were usually delegated to members of the tribal council, who then formed relevant committees in the villages (Van Koppen et al., 2002). However, during the Apartheid era, many of the traditional leaders were co-opted by the state or corrupted into furthering the aims of the Apartheid government (Turner and Meer, 2001). The ongoing dislocation of people and social engineering that occurred during the Apartheid era disrupted traditional forms of governance and customary law (Hauck and Sowman, 2003). In many instances the traditional authorities were viewed as agents of the state (Shackleton et al., 1998; Turner and Meer, 2001) facilitating the execution of Apartheid policies and laws. However, despite the erosion and corruption of these traditional institutions, customary values and practices have persisted and in some areas traditional institutions and management systems are still functional and respected.

In terms of the new legal framework governing IWRM in the democratic South Africa, the role of traditional leaders is unclear. As is the case with all the provinces in South Africa, the Eastern Cape has established a provincial HOTL which is responsible for 'dealing with matters concerned with traditional leadership, the role of traditional leaders, customary law and the customs of the community' (RSA, 1996). The kings/queens and chiefs/chieftainesses are the senior traditional leaders and their positions can only be occupied through inheritance. The headmen and sub-headmen are elected and are mainly responsible for monitoring activities in the community and giving feedback to the chief/chieftainess.

There are, however, no mechanisms set up to explicitly recognise traditional governance systems in the new democratic system. Despite the fact that traditional leaders are recognised by the South African Constitution (Sections 211212), their authority and powers in terms of water management are not augmented by legislation. The NWA does not explicitly recognise customary water management structures, practices and laws (Malzbender et al., 2005). Furthermore, according to Section 211(2) of the Constitution, the legislature is entitled to repeal existing customary law used by traditional leadership and amend it or replace it by statutory legislation. This establishes the superiority of statutory law.

\section{Findings}

\section{Diminished role of traditional leaders in WRM}

Findings from this research suggest that the authority of traditional leaders in terms of water management since the pre-colonial era has been eroded. More than $75 \%$ of the representatives of the Eastern Cape HOTL acknowledged that they were not aware of and informed about the current developments in water resource management in South Africa. Water service authorities (WSAs), water service providers (WSPs) and other state agencies such as DWA (formerly DWAF) and the Department of Agriculture (DoA), have now assumed authority in terms of water provision and management in the Eastern Cape Province. This was confirmed by interviews with representatives from government and water management agencies during the study.
Since July 2003, DWAF (now DWA) has allocated responsibility for water service provision and different aspects of water management to municipalities such as the Amathole District Municipality in the Eastern Cape. In the study area, Amatola Water, a private parastatal established in 1997 by the Minister of Water Affairs, is mandated by DWA to provide potable water to the municipalities. There is no legal obligation in the legislation that requires traditional leaders to be involved in management activities and decisions regarding water management. The Traditional Leadership and Governance Framework Act of 2003 only seeks to 'promote' partnerships between municipalities and traditional leaders. These partnerships are based on principles of mutual respect and are not legally binding (RSA, 2003). However, there is little evidence to suggest that such partnerships exist or are being formed.

Most provincial government departments in the Eastern Cape, as well as DWAF, DoA and officials involved in WSAs and WSPs, were of the opinion that traditional leaders do not have an influential role to play in water management even though they are important stakeholders. However, senior officers at the DWAF regional office acknowledged that traditional leaders had a role to play but that regional DWAF offices were waiting for the national government to develop strategies and provide guidelines to incorporate traditional leaders in water management institutions.

Based on work undertaken in Ghana, Ray (1996) argues that traditional leaders derive their legitimacy and authority from pre-colonial roots while the contemporary African state is a creation of, and successor to, the imposed colonial state. Because the state and traditional leaders derive their authority and legitimacy from different sources, their sovereignty and legitimacy in the post-colonial state is divided (Ray, 1996). Therefore, the structure and values of the 2 governance systems are in conflict which makes it difficult to bring them together (Ray, 1996; Meer and Campbell, 2003).

The HOTL in the Eastern Cape expressed the view that traditional leaders were not aware of the new water management policies and strategies developed in the late 1990s, or the requirement to establish new water management institutions such as CMAs and WUAs. It is worth noting that to date, only 1 fully functional CMA has been established, the Inkomati CMA (established in 2004). Therefore, the reason why most traditional leaders in the Eastern Cape are not aware of this process could be that the process of establishing these CMAs and WUAs is still in its infancy in many areas in the Eastern Cape.

\section{The role of traditional leaders in WUAs}

DWAF, with the assistance of the DoA, has largely been responsible for driving the process of establishing the WUAs in the Eastern Cape. Information gleaned from interviews and workshops found that traditional leaders participated in the public participation processes to inform the community about the requirement to set up a WUA for both eDikeni and Masikhanye, but they did not play any major part in the WUA establishment process thereafter. The management and institutional functioning of the WUAs is regulated by the constitution of the WUA and Section 92 of the Water Act which do not explicitly recognise a role for traditional leaders. Each WUA has a different constitution which may identify varying responsibilities for the traditional leaders depending on their influence within the local community. Discussions with members of the Masikhanye WUA indicated that the traditional leaders 
did not have any influential part to play in the establishment or operation of the WUA. However, in eDikeni, traditional leaders were consulted during the setting up of the WUA - especially with regard to access to land for the farmers. As part of the WUA constitutional requirement, the traditional leaders had representatives serving on the WUAs. However, the representatives of the traditional leaders do not have voting powers in the WUA committees which means that they have no influence in the decision-making process.

Discussions held with resource users and other stakeholders in the case study sites, revealed that the communication between the traditional leaders and the communities generally appears to be strong. The Burnshill headman in the Masikhanye WUA reported that they still conduct imbizos (community meetings) in association with the South African National Civic Organisation (SANCO). The imbizos are an important forum for information dissemination about general issues affecting the community. Thus, the traditional leaders are aware of the community needs in terms of water resources and they have the ability to convey the concerns and needs of the people to relevant structures. Several resource users stated that the roles and responsibilities of the traditional leaders need to be reinforced in the WUA committees so that their role as community advocates is strengthened so as to ensure that water management strategies meet community needs. However, in order for traditional leaders to fulfil this role they will need to be involved early in the process, including in the design of water management strategies and institutions so as to avoid contradictions between the structure and values of the state governance system and the traditional governance system. A further issue raised in this regard was the need for traditional leaders to be informed about the general principles and approaches underpinning the new water management regime, so that their input can be from an informed position.

Members of the HOTL in the Eastern Cape confirmed that traditional leaders still play an influential role in mediating conflicts through customary law. This claim was substantiated by inputs and stories from community members during the workshops and transect exercises. In most cases the main source of conflict relates to access to land and water resources. As was raised in the eDikeni workshop, the expectations for WUA farmers to develop farming-related business plans could culminate in conflicts related to land ownership and access as the farmers were trying to maximise the potential of their land. Conflicts related to land access and ownership mainly occurred in the villages due to lack of clarity regarding land-tenure systems in the communal lands.

At present, traditional leaders are still actively involved in land allocation in many villages surrounding the study area in collaboration with government agencies including the DoA, the Department of Public Works and local municipalities. The DoA is assisting farmers to monitor and manage land in the Zanyokwe Irrigation Scheme under the Masikhanye WUA. Since land tenure in rural communities is rooted in value systems, religious, social, political and cultural antecedents which are implemented by traditional leaders, it is important to have cohesion between traditional governance structures and government structures concerned with land distribution (Bernard, 2003).

A traditional leader at the HOTL reported that traditional leaders felt that their powers in terms of land distribution will be further diminished by the recently promulgated Communal Lands Rights Act, Act 11 of 2004 (RSA, 2004b) which requires that, in the Land Administration Structure
Committee, members of a traditional council represent $60 \%$, whilst other stakeholders such as municipalities hold $40 \%$. Despite acknowledging that this system is a formal way of distributing land, other traditional leaders feel that they will not be able to uphold customary practices of land tenure. Since the land tenure system is now state driven, many traditional leaders in the HOTL, as well as elderly people participating in workshops, argued that the influence of traditional governance systems in land distribution would be diminished. In some villages around the Masikhanye WUA, there are reports that some ward councillors are involved in land allocation. This suggests that there are overlapping responsibilities between ward councillors and traditional authorities. The roles and responsibilities of traditional leaders and that of newly-elected political leaders are not clearly defined, resulting in conflicts.

However, it should be acknowledged that there are certain inherent responsibilities and characteristics of traditional leaders which cannot be recognised within the state system. In many cases traditional leaders are respected within the community and are an important medium of communication, a role which cannot be assumed by the state because of the level of trust that exists between the community and traditional authorities. More so, the traditional knowledge possessed by state representatives is often incomparable with that of traditional leaders because traditional leaders are inherently intertwined with the socio-cultural system of a particular community. At a WUA meeting in the study area, it was observed that the ward councillor answered most concerns regarding community development issues whilst the chieftainess was a passive delegate. Some community members interviewed were of the opinion that since the ward councillors belonged to a political party they had more political influence than the traditional leaders. However, in other areas, for example in Burnshill village in the Masikhanye WUA, the chieftainess and the ward councillors worked together when allocating land and access to water sources.

In terms of the new WRM dispensation, water users are required to acquire licences. Many participants taking part in the transect exercise reported that in most cases where land is privately owned, access to water sources for cattle and the general public has been limited because access points are usually fenced. Thus, access to water by users in the communal areas is determined by the land-ownership system. This confirms the fact that land and water issues are intimately connected. Therefore, water management requires a holistic and integrated approach that incorporates other natural resources and is cognisant of traditional governance systems.

\section{Cultural and religious practices relevant to water management}

Many traditional communities have lost knowledge about their cultural and traditional practices and many, especially the youth, have repudiated them in favour of modern ways of living (EEU, 2007). These transformations, as well as the influence of western education systems, have led to behavioural changes, which have resulted in the abandonment of traditional ecological knowledge that is no longer relevant to many rural communities (Bernard, 2003). However, there were cultural and religious practices identified during the fieldwork and workshops which are still relevant to water management.

Cultural and religious practices such as baptism and initiation ceremonies are still practised in the villages covered by the 2 WUAs. It was reported by participants at the Masikhanye 


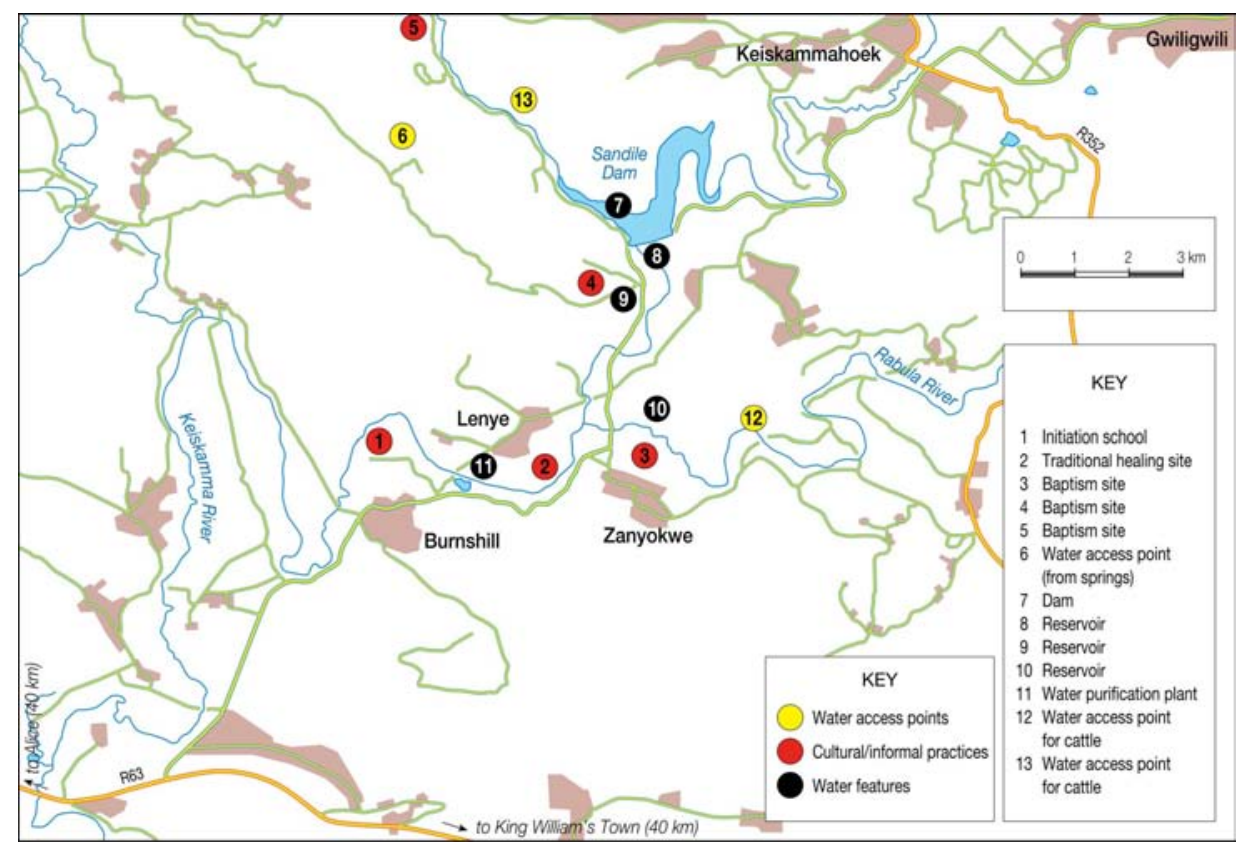

Figure 3

Masikhanye WUA

area - cultural and

religious sites

WUA workshop that there was an initiation school for girls at Burnshill village (Fig. 3). Baptisms and initiations were usually practised in the water along rivers such as the Keiskamma River. Participants reported that the Zionist priests baptised the devotees in the river whilst an elderly woman in the village was responsible for the initiation ceremonies. However, there were no specific sites which were designated for baptism and initiation ceremonies. A Zionist priest who baptised devotees reported that they chose the deepest part along a river for baptism. There was no evidence of restricted access to these sites.

Research participants also revealed that water plays a crucial role in the expulsion of evil spirits, curing illnesses and removing bad luck. Thus water plays an important role in the belief systems of certain individuals in the community. Water represents nourishment of both the body and the spirit (Zenani and Mistri, 2005). Even though the Water Act does not intend to disrupt religious and cultural practices, since WUAs will be accessing and using raw water along rivers which are also used for religious and cultural practices, it is crucial that these practices are acknowledged by local management structures so as to avoid disturbance of the socio-cultural fabric of these communities. Representatives from the HOTL indicated that many Zionist priests in the Eastern Cape now use the oceans for baptisms, probably because the water along rivers is polluted.

In research carried out by Fox (2005) in the Kat River Valley in WMA 15 which is adjacent to WMA $12,92 \%$ of the 44 respondents interviewed revealed that they are still practising traditional rituals which are linked to water. Over $80 \%$ of the respondents had performed traditional rituals in the past 2 years. The traditional communities believe that water is owned by God; therefore, everyone has a right to access it. The most commonly cited reason for the practice of these rituals was that it was an act of obedience and respect to their ancestors. However, in villages in the Mashikanye and eDikeni WUAs there was evidence that cultural practices and values were eroding. Modern forces have contributed to the 'disenchantment of the landscape' whereby respect for the spirits has rapidly disappeared (Bernard, 2003). The proximity to urban areas such as King Williams Town and Alice could be resulting in modern practices and behaviours infiltrating traditional ways of life.
Fox (2005) also reported that in the Kat River area the sacred pools are considered dangerous as they can result in drowning, especially if the river gods are angered. The participants at the Mashikanye WUA workshop reported that people do not grieve when this happens because they know the ancestors have been angered. Therefore, they have to perform certain rituals to appease them and retrieve the drowned body. Fox (2005) received inter alia the following responses when she asked respondents what would happen if the sacred pools were destroyed: 'It meant that the ancestors would be homeless'; 'We could be mentally ill. People could be mad'; and 'It means that our culture is dead' (Fox, 2005 p. 56).

Participants in the Masikhanye workshop reported that traditional healers continue to play a significant and influential role in the community. For example, the traditional healers conduct ceremonies at certain sites along the Keiskamma River, where they believe that the water spirits are present (Fig. 3). There are occasions when the traditional healers and their followers will spend days at these sites, communicating with the water spirits. The participants noted that there is a belief that if anyone disappears at certain sites where the water spirits are believed to exist, the villagers and family members are not allowed to grieve. They believe that the water spirits are imparting knowledge and skills to the individuals in healing. Near these water sites, there are certain plants which can be identified and used for healing purposes by traditional healers. Hence, it is important to consider these indigenous beliefs and practices in river management as they contribute to the community spiritual life and should be incorporated in management decisions relevant to the conservation and protection of the water resources.

\section{Customary rules and water management}

It is important that new water management institutions seek to understand how water is accessed, used and managed by traditional communities so that they can align the new institutions with informal institutions and practices that reflect community needs and way of life. A chief from HOTL explained that the river is divided into sections which have different water 


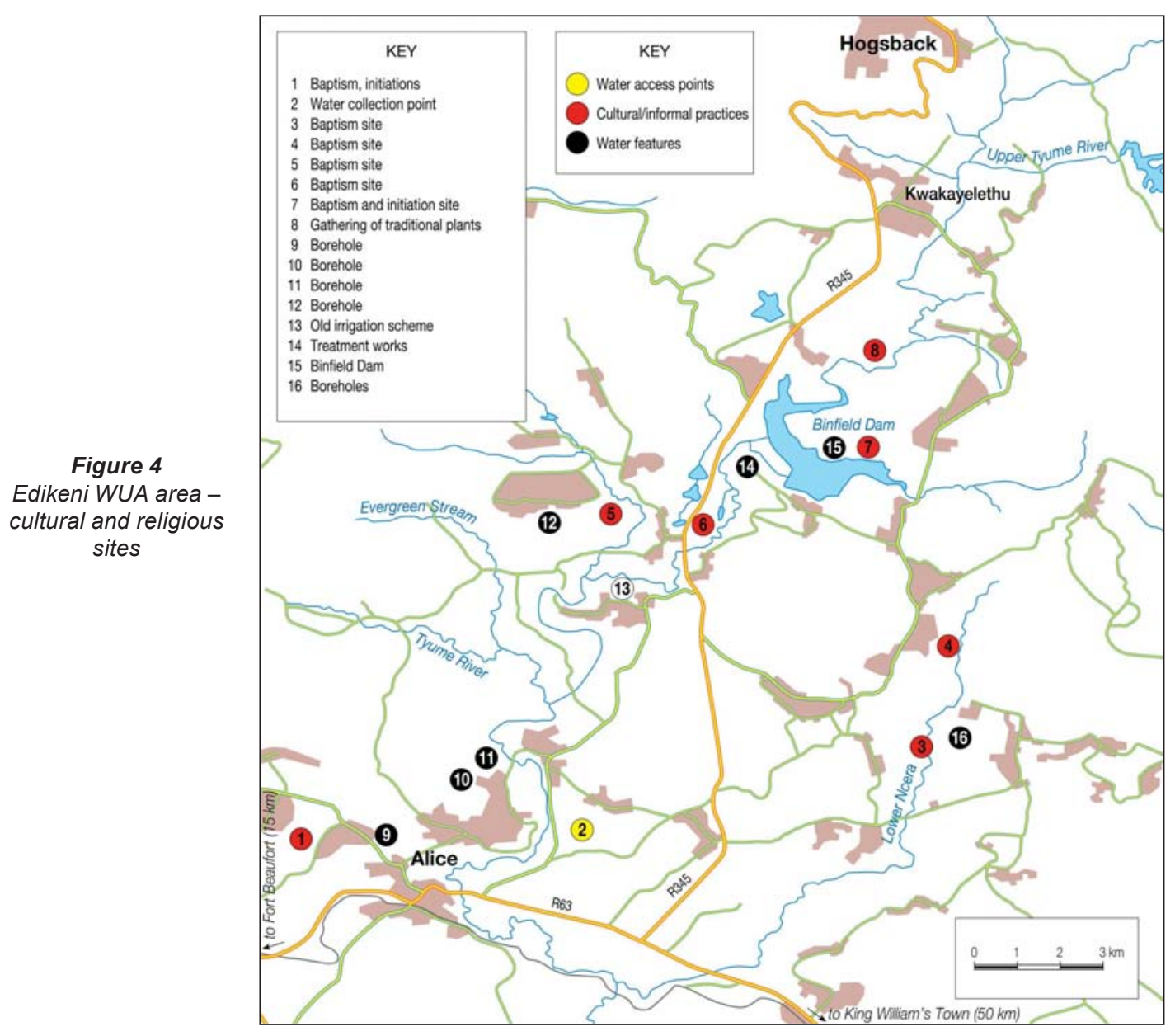

uses. The upstream section of a river may be used for drinking purposes, whilst the middle section of a river could be used for laundry and bathing, and the downstream section for cattle. Therefore, when farmers in the WUA abstract water for irrigation they should consider such traditional cultural practices so as to avoid polluting water sources which are used by others for drinking purposes. Even though most villages access drinking water from communal taps, there are some villages which still access drinking water from the river using buckets and fountains.

The research also revealed that cultural norms and values within a certain village did not necessarily coincide with those of an adjacent village. Most villages do not seem to coordinate their activities when devising rules in terms of access to and use of water along a river. One traditional leader from the HOTL acknowledged that their source of drinking water could be polluted by another village located upstream. A princess from Eastern Pondoland reported that when a member of the royal family dies, the family members will go at night and wash his/her clothes in a river far away from the village to turn away bad spirits. The lack of coherence between villages with regard to informal rules and cultural values could impact on water quality and be a potential source of conflict. Moreover, such inconsistencies could present challenges and difficulties in integrating traditional systems with modern state governance systems.

Dolsak and Ostrom (2003) argue that common pool regimes are sustainable when rules are created by a resource management group and regulated by them. Most villages in the study area access their water for domestic use from taps and boreholes. In relation to taps, the villages have informal rules, which are meant to curb the problem of pollution of groundwater and excessive use of water. In most villages which have taps, it is forbidden to wash clothes and dishes at the tap. People are required to fetch water using a container, and do the washing away from the water source. In many villages, stands are erected to avoid spillages. Containers with wide openings are also discouraged as opposed to containers with narrow openings because water could spill. Responses from women using the taps indicate that there are informal rules operating with respect to water management. For example, women acknowledge that doing laundry at the tap will leave the surrounding area soaked with water which will be polluted with detergents. Furthermore, when the area is soaked with water, cattle tramp on the surrounding area to drink water resulting in an unhealthy environment. In certain villages, the Amathole District Municipality is coordinating village water committees (VWC) which enforces some of these informal rules to promote effective management of potable water. This is evidence that informal or customary rules continue to play a role in conservation and management of water resources.

Despite the fact that modern technology (e.g. water quality testing) is frequently used to monitor and manage water sources, in certain villages traditional practices are still used to monitor and manage water sources. One traditional leader from the HOTL stated that in his village he would delegate tasks to households to monitor and preserve a fountain. The families usually practise a process called $u$ kapa (clearing the pond) which involves the removal of mud, resulting in the enlargement of the size of the resource, which in turn increases its 
water-holding capacity. Part of the responsibility involves protecting the fountain from cattle, usually by fencing it off with tree branches. The responsibility to manage the fountains will rotate among families in a village. Other cultural practices are aimed at maintaining water quality at drinking water fountains For instance, a drinking water fountain must be approached barefoot because it is believed that footwear will pollute the water. Similarly, only properly cleaned vessels are to be lowered into the well. One elderly man noted that in the Xhosa tradition, it is believed that if you use a dirty vessel to collect water from a well you will scoop up a snake. Multipurpose sources, such as washing and bathing are supposed to be performed at a distance so that wastewater does not spill over or drain into the water source. Such practices are inculcated in children through the process of socialisation early in life. These customary rules are thus still prevalent and contribute to promoting improved water quality and should be formally integrated into new local water management systems.

\section{Discussion and conclusions}

The findings from this research reveal that both state and traditional governance systems are relevant to water management in the study area although the former is clearly the dominant system. Water management in South Africa is essentially guided by state-driven policies and strategies which are based on statutory legal systems. However, many rural areas in South Africa have plural legal systems and customary rules still apply. Land and water resources are thus regulated by different legal provisions and institutions, including statutory and customary law.

In terms of current policy frameworks and legislation governing water resource management in South Africa, the new institutional dispensation of devolving aspects of water management to the local level through CMAs and WUAs is concerned with improving service provision and demand management. On the other hand, the traditional governance systems have a common pool resource management function which involves decision-making based on communityestablished rules and social and cultural practices to control access to, use and ownership of water resources. While these new WMIs actively seek to involve local resource users and key stakeholders in water management decisions through consultation and representation on boards and associations, the overriding purpose of these institutions is to implement state water policy and law. Although these forums do provide an opportunity for traditional leaders to participate, there is no explicit requirement that relevant indigenous local knowledge and customary practices and rules be considered in the formulation of new local level management systems. Thus the extent to which these traditional knowledge and governance systems are incorporated into new management structures and systems is largely dependent on the individuals driving the process and their recognition of the potential value of incorporating this knowledge, customary practices and rules.

Water is a common pool resource that requires joint management and decision making as neither the state, private sector nor the local communities can effectively manage water alone (Meinzen-Dick et al., 2006; Baland and Platteau, 1996). Integrating the dominant state-driven and the communitybased common pool system will definitely present challenges to policy makers as the systems could potentially clash. Traditional leaders derive their legitimacy and authority from pre-colonial roots while the contemporary African state is a creation of, and successor to, the imposed colonial state (Ray,
1996). The tension is reinforced by other dualities at the local level, for example the role of the state through its governance structures such as government departments, municipalities and political structures.

Our research suggests that there seems to be limited space in these new WMIs at the local level for the application of customary rules because most of the individuals who are responsible for the implementation of the WUAs are answerable to state institutions such as DWA and district municipalities. Hence, if new water management institutions do not engage with traditional governance systems, these new institutions are likely to marginalise and replace these customary systems which contribute to water resource management objectives. The repercussions of this could be negative for marginalised villagers who are more acquainted with indigenous knowledge systems and customary laws found within traditional governance systems. Multiple users of common pool resources such as water often have a shared understanding of who should use resources, how and when such resources should be used, and how much of the resource can be used. These arrangements are often lost in tenure reforms, such as privatisation of water resources through licences, because such conditionalities are seen to increase transaction costs and thus hinder the redistribution of property rights (Meinzen-Dick and Nkonya, 2005).

This research indicates that remnants of traditional governance systems concerning water management obviously still play a potentially important part in the way people think and act in regard to the use of water resources. Moreover, traditional leaders are still playing an important role in their communities mainly with respect to conflict resolution and land allocation. Given that decisions regarding access to and use of land are integrally linked to water allocation systems, an understanding of these traditional systems should contribute to a more integrated and relevant management system. Traditional management systems may also be effectively used for water management because they are localised (e.g. chiefs and headmen) as compared to conventional systems which require many more resources to penetrate to the local level.

It will be beneficial for local water users if WUAs build upon the indigenous institutions that have been managing access to and use of the water resources in the rural communities. Furthermore, most rural communities tend to be familiar with and understand the customary laws better than the new water management strategies because the customary laws relate to their belief systems and their day-to-day interaction with water. In customary law and practice, water is treated as a god-given common pool resource that all are entitled to use and cannot be owned individually (Bernard, 2003). However, under state governance water is treated as an economic good where individuals have to pay for the resource. This is an indication that rights to water resources under customary law are fundamentally different from the requirements of statutory law. As evidenced in the study area, customary laws play a role in determining access to and use of natural resources and resolving management conflicts. Hence, it is possible that neglect of customary laws may cause IWRM implementation efforts to fail, or may have a negative consequence for individuals and groups who were better served by customary-based systems (NRI, 2004). Moreover, if customary laws are acknowledged and incorporated into the current legal framework for WRM, there is likely to be greater community support for enforcement of these laws. Thus there is a need for understanding and coherence between the customary beliefs and laws and the state-driven systems. 
Traditional governance systems, including customary laws and cultural and religious practices thus have an important role to play in achieving the dual purposes of the WUAs. The WUAs provide a mechanism for water demand management but also nurture a common pool regime for resource management at a local level. These are potentially conflicting aims and policy makers need to be aware of the confusion that may result at local level amongst stakeholders as a result of this. This is mainly because the structures and values of common pool resource regimes such as traditional governance systems and state-driven systems are different. Therefore, the challenge is to decide on how, and the extent to which, traditional leaders and existing customary rules and practices and indigenous knowledge systems can be incorporated into the new water resource management systems in South Africa. Failure to acknowledge and incorporate aspects of these traditional governance systems may undermine the very purpose of the Act, namely to facilitate access to water for productive purposes for the poor, through establishment of new water management institutions and equitable allocation of water resources.

\section{Acknowledgements}

We would like to gratefully acknowledge the financial assistance of the Water Research Commission (WRC) in South Africa which provided funds to conduct the research. We are also grateful to the Department of Water Affairs (DWA) and to staff members of the Department of Agriculture (DoA) in the Eastern Cape Province who assisted in co-ordinating the field work in the case study areas. We also extend thanks to the following groups and individuals for their useful information and insights: Members of the House of Traditional Leaders (HOTL) in the Eastern Cape, traditional leaders in the study area, members of the eDikeni and Masikhanye Water User Associations and local communities in the study areas.

\section{References}

BALAND J and PLATTEAU J (1996) Coordination problems in local level resource management. J. Dev. Econ. 53 197-210.

BERNARD P (2003) Ecological implications of water spirit beliefs in Southern Africa: The need to protect knowledge, nature and resource rights. USDA Forest Service Proc. RMS 27 148-153.

CLEAVER F, FRANKS T, BOESTEN J and KIIRE A (2005) Water Governance and Poverty: What Works for the Poor? University of Bradford, Bradford. URL: http://www.bradford.ac.uk/acad/bcid eesearch.wg (Accessed on?)

DENZIN NK (1970) The Research Act: A Theoretical Introduction to Sociological Methods. Aldine, Chicago.

DOLSAK N and OSTROM E (2003) The Commons in the New Millennium: Challenges and Adaptation. MIT Press, London.

ENVIRONMENTAL EVALUATION UNIT (EEU) (2007) Institutional Dimensions of Water Resource Management in South Africa: Socio-Cultural Perspectives. Draft unpublished report. Environmental Evaluation Unit, University of Cape Town, Cape Town.

FOX HE (2005) The Role of Anthropogenic Disturbance in the Creation of a Socio-Ecological Landscape. Unpublished Masters Thesis, Rhodes University, South Africa.

FRANKS T, TONER A, GOLDMAN I, HOWLETT D, MUHUMUZA F, KAMUZORA F and TAMASANE T (2004) The Institutional Impacts of Adopting a Livelihoods Approach to Managing Development Interventions. Bradford Centre for International Development, Bradford. URL: http://www.bradford.ac.uk/acad, bcid/research/poverty/projects/goodbye/papers

GLAZEWSKI J (2005) Environmental Law in South Africa (2 ${ }^{\text {nd }}$ edn.). LexisNexis Butterworths, Durban, South Africa.
HAUCK M and SOWMAN M (2003) (eds.) Waves of change: Coastal and Fisheries Co-Management in Southern Africa. University of Cape Town Press, Cape Town, South Africa.

HIRSCH E and O'HANLON M (1995) The Anthropology of Landscape: Perspectives on Place and Space. Clarendon Press, Oxford, UK.

JICK TD (1979) Mixing quantitative and qualitative methods: Triangulation in action. Adm. Sci. Q. 24 (4) 601-611.

KIMCHI J, POLIVKA B and STEVENSON JS (1991) Triangulation: Operational definitions. Nurs. Res. 40 (6) 364-366.

MALZBENDER D, GOLDIN J, TURTON A and EARLE A (2005) Traditional water governance and South Africa's National Water Act - tensions or cooperation. Proc. Plural Legislation Frameworks for Rural Water Management in Africa. 26-28 January 2005, Johannesburg, South Africa. International Water Management Institute (IWMI).

MEER T and CAMPBELL G (2004) Traditional leadership in democratic South Africa. Democracy Development Programme, Durban.

MEINZEN-DICK R, MWANGI E and DOHRN S (2006) Securing the Commons. Policy Brief Number 4. International Food Policy Research Institute (IFPRI), Washington, USA.

MEINZEN-DICK R and NKONYA L (2005) Understanding legal pluralism in water rights: Lessons from Africa and Asia. Proc. Plural Legislation Frameworks for Rural Water Management in Africa. 26-28 January 2005, Johannesburg. South Africa. International Water Management Institute (IWMI).

MULLER A M (2000) How national water policy is helping to achieve South Africa's development vision. In: Abernethy CL (ed.) Intersectoral Management of River Basins. International Water Management Institute (IWMI), Sri-Lanka.

NATURAL RESOURCES INSTITUTE (NRI) (2004) Guidelines for Catchment Managers: Building upon Customary Practices in Implementing IWRM in Africa: Good Practice Guidelines for Water Managers. Natural Resources Institute (NRI), University of Greenwich at Medway, UK

RAY ID (1996) Divided sovereignty: Traditional authority and the state in Ghana. J. Leg. Pluralism \& Unofficial Law 37/38 181-202.

REPUBLIC OF SOUTH AFRICA (RSA) (1996) Constitution of the Republic of South Africa (18 of 1996). RSA, Pretoria, South Africa.

REPUBLIC OF SOUTH AFRICA (RSA) (1997) Water Services Act (108 of 1997). RSA, Pretoria, South Africa.

REPUBLIC OF SOUTH AFRICA (RSA) (1998) National Water Act (36 of 1998). RSA, Pretoria, South Africa.

REPUBLIC OF SOUTH AFRICA (RSA) (1999) Draft: Water Conservation and Demand Management National Strategy Framework. Department of Water Affairs and Forestry, Pretoria, South Africa.

REPUBLIC OF SOUTH AFRICA (RSA) (2003) White Paper on Traditional Leadership and Governance. Department of Provincial and Local Government, Pretoria, South Africa.

REPUBLIC OF SOUTH AFRICA (RSA) (2004a) The National Water Resource Strategy. Department of Water Affairs and Forestry, Pretoria, South Africa.

REPUBLIC OF SOUTH AFRICA (RSA) (2004b) Communal Land Rights Act (11 of 2004). RSA, Pretoria, South Africa.

SHACKLETON SE, VON MALTITZ G and EVANS J (1998) Factors, conditions and criteria for the successful management of natural resources held under a common property regime: A South African perspective. Occasional Paper No. 8, Programme for Land and Agrarian Studies (PLAAS), University of the Western Cape, Cape Town.

SCHREINER B, MOHAPI N, VAN KOPPEN B (2004) Washing away poverty: Water democracy and gendered poverty eradication in South Africa. Nat. Resour. Forum 28 (3) 171-178.

SOKILE CS, KASHAIGILI JJ, KADIGI RMJ (2003) Towards an integrated water resource management in Tanzania: The role of appropriate institutional framework in Rufiji Basin. Phys. Chem. of the Earth 28 1015-1023.

TEWARI DD (2001) An analysis of evolution of water rights in South African society: An account of three hundred years. Proc. The Role of Water in History and Development. 10-12 August, 2001. Bergen, Norway. International Water History Association. 
TURNER S and MEER S (2001) Conservation by People in South Africa: Findings from TRANSFORM Monitoring and Evaluation, 1999. Research Report No. 7. Programme for Land and Agrarian Studies (PLAAS), University of Western Cape, Cape Town.

VAN KOPPEN B, JHA N and MERREY DJ (2002) Redressing racial inequities through water law in South Africa: Interaction and contest among legal frameworks. In: Pradhan R (ed.) Legal Pluralism and Unofficial Law in Social, Economic and Political Development. Proc. XIII ${ }^{\text {th }}$ International Congress of the
Commission on Folk Law and Legal Pluralism. 7-10 April 2002, Chiang Mai, Thailand. Volume 2: International Centre for the Study of Nature, Environment and Culture, Kathmandu, Nepal. pp. 201-219.

ZENANI V and MISTRI A (2005) A Desktop Study on the Cultural and Religious Uses of Water using Regional Case Studies from South Africa. Department of Water Affairs and Forestry, Pretoria, South Africa. 